\title{
Kinetic Study on Esterification of Ascorbyl Oleate Catalyzed by Lipase NS 88011
}

\author{
Karine Angélica Dalla Costa ${ }^{1(\mathbb{D})}$, Thiago André Weschenfelder ${ }^{1(\mathbb{D})}$, Clarice Steffens ${ }^{1}{ }^{(\mathbb{D}}$, Débora de \\ Oliveira $^{2}$ (D), Rogério Luis Cansian ${ }^{1}$ (D), Rogério Marcos Dallago ${ }^{1}$ (D), Jamile Zeni 1,*(D), \\ Natalia Paroul 1 (D) \\ 1 Department of Food Engineering, URI - Erechim, Av.7 de Setembro, 1621, CEP 99709-910, Erechim, RS, Brazil; \\ karinedallacosta@hotmail.com (K.A.D.C); thiago.weschenfelder@gmail.com (T.A.W.); clarices@uricer.edu.br (C.S.); \\ cansian@uri.com.br (R.L.C.); dallago@uricer.edu.br (R.M.D.); nparoul@uricer.edu.br (N.P.); \\ 2 Department of Chemistry and Food Engineering, Federal University of Santa Catarina, CEP 88040-900, Florianópolis, \\ SC, Brazil; debora@enq.ufsc.br (D.O.); \\ * Correspondence: jamilezeni@uricer.edu.br;
}

Scopus Author ID 35323468700

Received: 13.06.2020; Revised: 19.07.2020; Accepted: 20.07.2020; Published: 23.07.2020

Abstract: In this study, bisubstrate kinetics mechanism models were correlated with the experimental data of ascorbyl oleate using the new lipase preparation, Candida antarctica NS 88011, and kinetic parameters (Vmax, Km, and Ki) were estimated. The highest conversion $(49.42 \%)$ was observed at 1 $\mathrm{h}$ of reaction using the ascorbic acid/oleic acid molar ratio of $1: 9,70{ }^{\circ} \mathrm{C}$ and $30 \%$ of enzymatic loading. The Ping Pong Bi-Bi model showed better congruence with the experimental data for all the effects evaluated. The kinetic constants showed that the lipase had an identical affinity, with a value of 0.81 for both substrates and inhibitory constant (Ki) of ascorbic acid (1.959) much higher than oleic acid (0.0008). It has been demonstrated that lipase has good operational stability $\left(14^{\text {th }}\right.$ cycle). The results obtained with the new immobilized enzyme are valuable to elucidate the reaction mechanism. In addition, it represents an important contribution to optimize the reaction and create strategies to increase the productivity of the esters of vitamin C.

Keywords: Kinetic; enzymatic esterification; ascorbic acid; oleic acid; Ping-Pong Bi-Bi mechanism.

(C) 2020 by the authors. This article is an open-access article distributed under the terms and conditions of the Creative Commons Attribution (CC BY) license (https://creativecommons.org/licenses/by/4.0/).

\section{Introduction}

An antioxidant is a type of food additive used for prolonging the shelf life of food [1] and are classified into synthetic and natural. Synthetic antioxidants such as butylated hydroxyanisole (BHA), butylated hydroxytoluene (BHT), and tert-butylhydroxyquinone (TBHQ) are widely used in the food industry due to their high antioxidant capacity and outstanding performance in the retardation of oxidation reactions [2]. However, in recent years there has been a strong interest in replacing synthetic antioxidants with natural compounds because of possible detrimental health effects, such as toxicity and carcinogenesis promotion $[3,4]$.

Vitamin C (L-ascorbic acid) is one of the most abundant natural antioxidants used in food, pharmaceutical, and cosmetic fields. However, the polar nature of ascorbic acid makes its application limited. The solubility problem can be contour transforming the hydrophilic acid into a hydrophobic ester [5-7]. 
Many esters derived from ascorbic acids, such as ascorbyl oleate, ascorbyl palmitate, ascorbyl linoleate, were synthesized using commercial immobilized high-cost lipase (Novozym ${ }^{\circledR} 435$ ) [8-12]. However, the kinetic studies required to define the appropriate model of the reaction and possible inhibitions of the substrates were rarely reported. The knowledge of reaction kinetics is of great importance, not only to elucidate the mechanism of this reaction but to obtain reliable information about the rate of product formation and changes in the experimental system for further industrial expansion.

Lipases are found to be very efficient catalysts for esterification reactions [13]. Several kinetic studies of the enzyme-catalyzed synthesis of esters have been carried out with lipases of different origins using alcohols and acids of different chain-lengths and structures [14-18], because in the esters production using biocatalyst, it is important to determinate the optimal conditions of reactions for the maximum efficiency of the process along with its reaction kinetics [19]. The reaction conditions, such as temperature, enzyme concentration, molar ratio, stirring of the reaction mixture, among others, may directly influence the choice of the kinetic model that best represents the experimental data [20]. Due to the importance of the proper evaluation, lipase-catalyzed esterification has been done through several models for different combinations of substrates and enzymes over the years, being reported in the literature the mechanisms of Ping Pong $\mathrm{Bi}-\mathrm{Bi}$, ordered $\mathrm{Bi}-\mathrm{Bi}$, and random $\mathrm{Bi}-\mathrm{Bi}$ [21-27]. Although the synthesis of ascorbic acid esters using lipases Novozym 435, Lipozyme TL-IM and Lipozyme RM-IM has already been documented, the high price of these biocatalysts is still one of the main obstacles in the commercialization of the process [11,28,29]. NS 88011 is a novel preparation immobilized on low-cost material, taken from fraction B of Candida antarctica, without further information described by the manufacturer, which may be used in enzymatic esterification. Meanwhile, there are no articles that report the detailed synthesis of ascorbyl oleate using NS 8801 in the literature, as well as its validation with a kinetic model and estimation of the kinetic constants. In this context, this work aims the maximization of various conditions of esterification, such as a substrate molar ratio, enzyme loading and temperature of ascorbyl oleate, followed by the validation of the bi substrate kinetic model (Ping Pong Bi-Bi, ordered $\mathrm{Bi}-\mathrm{Bi}$, and random $\mathrm{Bi}-\mathrm{Bi}$ ), and estimation of kinetic parameters $\mathrm{Vmax}, \mathrm{Km}$, and $\mathrm{Ki}$. The influence of the temperature, according to Arrhenius' law and the operational stability of the enzyme, was also reported.

\section{Materials and Methods}

\subsection{Substrates and enzymes.}

The chemicals used in the study were all of the analytical grades and used without further purification: ascorbic acid (99\% Sigma-Aldrich, USA), oleic acid (97\% SigmaAldrich, USA), tert-butanol (P.A. Merk). The commercial lipase used as catalyst was Candida antarctica (NS 88011) immobilized on a hydrophobic polymer resin, purchased from Novozymes Brazil (Araucária, PR, Brazil).

\subsection{Kinetic evaluation of enzymatic production of ascorbyl oleate.}

Kinetic experiments were performed with substrates molar ratio of 1:4 (3,83:15,31 mmol), 1:9 (1,84:16,55 mmol) e 1:14 (1,21:16,95 mmol) (ascorbic acid/oleic acid), enzyme concentration of 15,20 and $30 \mathrm{wt} \%$ and temperature ranging from 40 to $70^{\circ} \mathrm{C}$. All reactions were performed with $20 \mathrm{wt} \%$ of a molecular sieve. These conditions were based on 
preliminary tests and data from the literature [8,30]. The esterification reactions were performed by preparing the reactive mixture of ascorbic acid, oleic acid, and tert-butanol solvent (at pre-established conditions) in a volumetric flask of $50 \mathrm{~mL}$. After the complete dissolution of the substrates, the mixture was transferred in a $250 \mathrm{ml}$ Erlenmeyer flask, and the enzyme and molecular sieves were added. Aliquots of $1 \mathrm{~mL}$ were withdrawn from the reaction medium at $0,0.5,1,1.5,2,3,4,5$, and $6 \mathrm{~h}$. All experiments were carried out in an orbital shaker at constant agitation of $125 \mathrm{rpm}$. After each experimental run, the enzyme was separated from the reactional medium and washed twice with $10 \mathrm{~mL}$ of $\mathrm{n}$-hexane. The recuperated enzyme was kept in a desiccator for $24 \mathrm{~h}$, and after this period, the enzyme activity was determined. All experiments were performed in triplicate and on three separate occasions.

\subsection{Determination of reaction conversion.}

The yield of the reaction was indirectly determined by the use of the limit reagent (ascorbic acid) by titration with $0.002 \mathrm{~mol} / \mathrm{L}$ potassium iodate $\left(\mathrm{KIO}_{3}\right)$, in the medium acidic solution until the appearance of persistent blue stain for fifteen seconds (methodology adapted from Instituto Adolfo Lutz [31]). Reaction conversion was calculated according to Equation 1.

$$
\text { Vitamin } C\left(\frac{m g}{100 m L}\right)=\frac{\left(V_{T} \times F\right)}{V_{a}} \times 100
$$

Where: $V_{T}$ represents the volume of titrant $\left(\mathrm{KIO}_{3}\right)$ spent on titration $(\mathrm{mL}) ; F$ is 0.886 (mass of ascorbic acid (mg), referring to $1 \mathrm{~mL}$ of $\mathrm{KIO}_{3}(0.002 \mathrm{~mol} / \mathrm{L}) ; \mathrm{Va}$ is the sample volume $(\mathrm{mL})$.

The kinetic evolution of the reaction was evaluated by Equation 2:

$$
V(m o l / L h)=\frac{\left(\left[A A_{i}\right]-\left[A A_{f}\right]\right)}{t}
$$

Where: $\mathrm{V}$ is the reaction rate, $\left[\mathrm{AA}_{\mathrm{i}}\right]$ and $\left[\mathrm{AA}_{f}\right]$ are the initial and final molar concentration, respectively ( $\mathrm{mol} / \mathrm{L})$ and $\mathrm{t}$ is the time $(\mathrm{h})$.

\subsection{Determination of activation energy.}

Activation energy at temperatures from 40 to $70{ }^{\circ} \mathrm{C}$ was calculated by the non-linear regression method using the least-squares objective function with the non-linear Generalized Reduced Gradient (GRG) algorithm. This calculation was carried out using the Open Microsoft Excel, applying the Arrhenius equation (Equation 3).

$$
V_{o}=A^{-E a / R T}
$$

Where: Vo represents the initial rate of reaction, $\mathrm{A}$ is the constant of the Arrhenius, Ea is the activation energy, $\mathrm{R}$ is the universal gas constant, and $\mathrm{T}$ is the temperature.

\subsection{Mechanism of the esterification reaction.}

Two substrates, ascorbic acid [A] and oleic acid [B] are attached to the immobilized lipase NS 88011 [E] in a specific or random order to form a complex [AEB], which reacts to form the ascorbyl oleate $[\mathrm{P}]$ and water $[\mathrm{Q}]$ products. A scheme of the esterification reaction for ascorbyl oleate is shown in Fig. 1.

The data obtained were fitted with Michaelis-Menten kinetics using three different kinetic models (Ping Pong $\mathrm{Bi}-\mathrm{Bi}$, ordered $\mathrm{Bi}-\mathrm{Bi}$, and random $\mathrm{Bi}-\mathrm{Bi}$ of bi substrates), as reported by Kuperkar et al. [23]. These three generalized models of two substrates and two products were used because they describe the product formation only after the formation of the enzyme complex-two substrates. Non-linear regression analysis was used to estimate the kinetic parameters: maximum velocity (Vmax), inhibition $(\mathrm{Ki})$, and dissociation $(\mathrm{Km})$, using, The 
non-linear GRG algorithm with a convergence of 0.0001 and a population size of 100 was used to minimize the least-squares objective function in Open Microsoft Excel. The determination coefficients $\left(\mathrm{R}^{2}\right)$ and root mean square deviation (RMSD) were determined for each experimental condition and model evaluated.
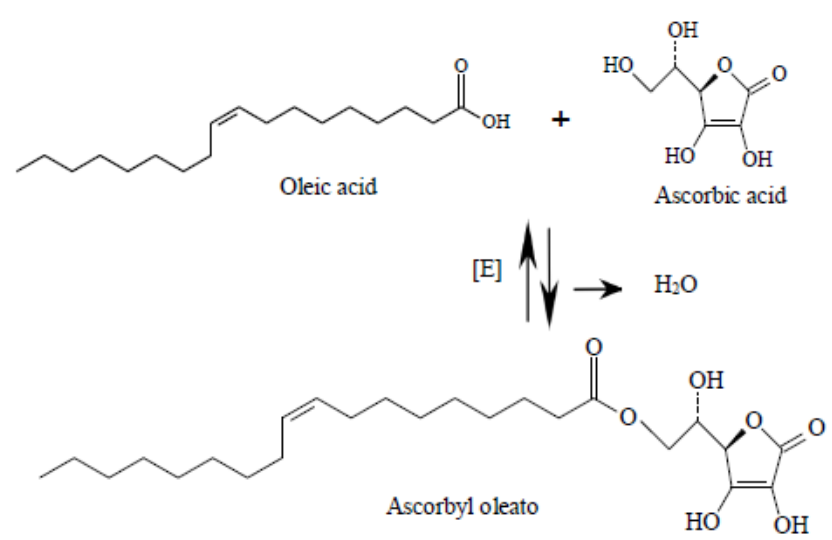

Figure 1. Reaction scheme of ascorbyl oleate synthesis by ascorbic acid synthesis [A] with oleic acid [B] using immobilized lipase NS 88011.

2.5.1. Ping Pong Bi-Bi mechanism.

Following the reported by Kuperkar et al. [23], Ping Pong Bi-Bi mechanism describes a dual displacement Bi-Bi mechanism shown in Fig. 2.

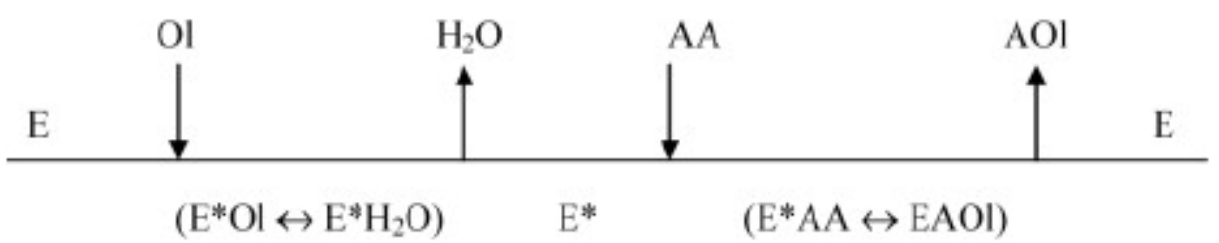

Figure 2. Ping Pong Bi-Bi kinetic mechanism.

According to Kuperkar [23], in this mechanism, first, only one substrate (acyl donor oleic acid) is attached to the active site of the lipase molecule, and the acyl-enzyme complex [EO1] is formed. Then, the first product (water) $\left[\mathrm{H}_{2} \mathrm{O}\right]$ is released, followed by the acyl receptor binding (ascorbic acid) [AA]. In the final step, the ester (ascorbyl oleate) [AOl] is released. Based on the proposed mechanism, the expression for reaction rate, with inhibition of both substrates (ascorbic acid/oleic acid) is described according to Equation 4, proposed by Kuperkar et al. [23].

$$
V=\frac{V_{\max }}{[A][B]+K m_{b}[A]+\left(1+[A] / K i_{a}\right)+K m_{a}[B]+\left(1+[B] / K i_{b}\right)}
$$

Where: $\mathrm{V}$ represents the reaction rate, $\mathrm{V}_{\max }$ the maximum reaction rate, $[\mathrm{A}]$ and $[\mathrm{B}]$ are the concentrations of ascorbic acid and oleic acid, $\mathrm{Km}_{\mathrm{a}}$ and $\mathrm{Km}_{\mathrm{b}}$, Michaelis constants, of [A] and [B], $\mathrm{Ki}_{\mathrm{a}}$ and $\mathrm{Ki}_{\mathrm{b}}$ are the inhibition constants of [A] and [B], respectively.

\subsubsection{Ordered Bi-Bi mechanism.}

In the ordered $\mathrm{Bi}-\mathrm{Bi}$ mechanism, Kuperkar et al. [23] proposed that the enzyme reacts with two substrates, i.e., ascorbic acid and oleic acid, in an orderly manner, providing two 
products (ester and water), which are also released in an orderly manner. The reaction rate equation for the ordered $\mathrm{Bi}-\mathrm{Bi}$ mechanism is described according to Equation 5 [23].

$$
V=\frac{V_{\max }}{[A][B]+K m_{b}[A]+K m_{a}[B]\left(1+[B] / K i_{a}\right)+K i_{a} K m_{b}(1+[B] / K i)}
$$

Where $\mathrm{V}$ represents the reaction rate, Vmax the maximum reaction rate, $[\mathrm{A}]$ and $[\mathrm{B}]$ are the concentrations of ascorbic acid and oleic acid, Kma and Kmb, Michaelis constants, of [A] and [B], Kia is the inhibition constant of [A], and $\mathrm{Ki}$ is the inhibition constant by both substrates.

\subsubsection{Random Bi-Bi mechanism.}

The random $\mathrm{Bi}-\mathrm{Bi}$ mechanism is obtained when the substrates bind to the enzyme in random order and provide products. The fixed concentration of one substrate alters the affinity of the other substrate in relation to the enzyme. The final reaction rate following the model proposed by Kuperkar et al. [23] is described in Equation (6).

$$
V=\frac{V_{\max }}{[A][B]+K m_{b}[A]+K m_{a}[A] K i_{a} K m_{b}}
$$

Where $\mathrm{V}$ represents the reaction rate, $\mathrm{V}_{\max }$ the maximum reaction rate, $[\mathrm{A}]$ and $[\mathrm{B}]$ are the concentrations of ascorbic acid and oleic acid, $\mathrm{Km}_{\mathrm{a}}$ and $\mathrm{Km}_{\mathrm{b}}$, Michaelis constants, of [A] and [B], $\mathrm{Ki}_{\mathrm{a}}$ is the inhibition constant of $[\mathrm{A}]$.

\subsection{Determination of operational stability.}

The experiments performed to determine the operational stability of the enzyme were conducted in the best condition obtained in the enzymatic production of ascorbyl oleate. For this, after the reaction, the enzyme was separated by conventional filtration, washed twice with $10 \mathrm{~mL}$ of $\mathrm{n}$-hexane and vacuum filtered. The solvent was removed maintained in a desiccator for $30 \mathrm{~min}$ at $60{ }^{\circ} \mathrm{C}$ for $24 \mathrm{~h}$. After ward, the enzyme was reused in a new batch. This process was carried out until the enzyme lost $50 \%$ of its initial esterification activity (residual activity).

\subsection{Determination of esterification activity.}

The esterification activity of the enzyme was quantified by the synthesis reaction of oleic acid and ethanol (mole ratio of 1:1, v/v), as described by Rigo et al. [32]. One unit of enzymatic activity (U) was defined as the amount of enzyme necessary to $1 \mu \mathrm{mol}$ of fatty acid per minute under the described assay conditions [33].

\section{Results and Discussion}

Maximization of the initial molar ratio of substrates, reaction temperature, and enzymatic loading parameters was performed based on maximum conversion and high reaction rates. A kinetic investigation was also performed to determine the reaction mechanism in each condition, and thus to promote the estimation of the kinetic parameters. In addition, the operational stability of the enzyme in the condition of maximum conversion was evaluated.

\subsection{Effects of molar ratio.}

The substrates molar ratio is one of the most important variables affecting the process conversion [9]. The effect of the molar ratio of ascorbic acid:oleic acid (1:4, 1:9, and 1:14) in the conversion is shown in Fig. 3. 


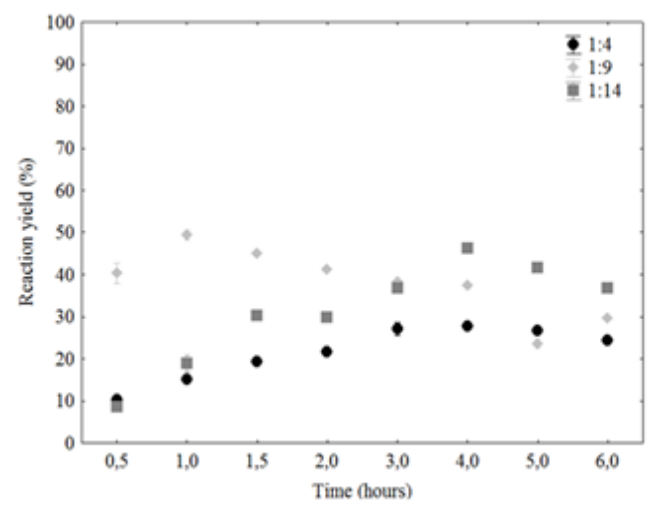

Figure 3. Kinetics of ascorbyl oleate production at different molar ratios of ascorbic acid/oleic acid (1:4, 1:9 and $1: 14$ ) at $70{ }^{\circ} \mathrm{C}, 30 \mathrm{wt} \%$ of enzyme concentration, $125 \mathrm{rpm}$ in a tert-butanol solvent system.

The use of 1:9 molar ratio (ascorbic acid/oleic acid) led to the highest yield after $1 \mathrm{~h}$ of the reaction $(49.42 \pm 1.57 \%)$. In low molar ratios, there is a limitation in mass transfer, also with the addition of an excess of one of the substrates (oleic acid) it provides the fastest formation of the enzymatic acyl complex, which can shift the reaction balance to product formation [10]. However, an excessive amount of oleic acid can dilute the concentration of ascorbic acid in the reaction system, which further reduces the collision frequency of ascorbic acid and lipase. This explains the decreased conversion obtained for 1:14 molar ration (ascorbic acid/oleic acid) [34].

Based on the results obtained, the substrates' molar ratio for ascorbyl oleate production was fixed at 1:9 (ascorbic acid/oleic acid).

\subsection{Effect of temperature.}

The effect of temperature on the esterification reactions was evaluated at $40-70{ }^{\circ} \mathrm{C}$ (Fig. 4), maintaining constant the following parameters: 1:9 of ascorbic acid: oleic acid ratio, $30 \%$ of enzymatic charge (w/w of substrates) and agitation rate of $125 \mathrm{rpm}$.

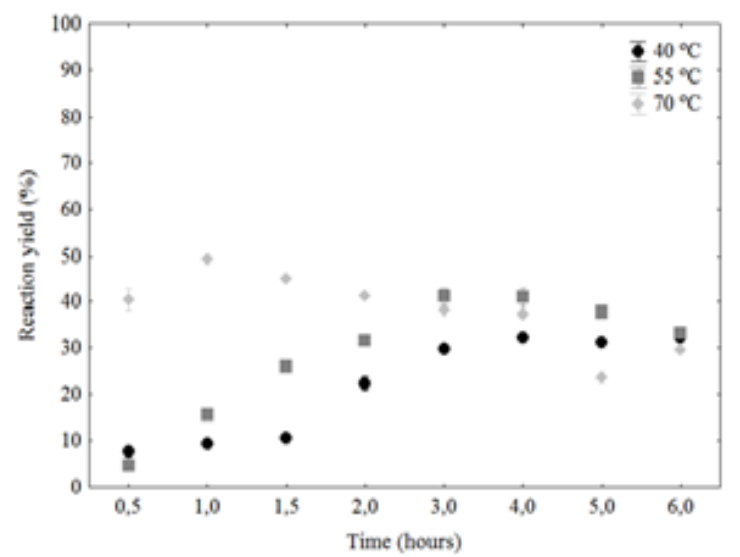

Figure 4. Kinetics of ascorbyl oleate production at different temperatures $\left(40,55\right.$, and $\left.70{ }^{\circ} \mathrm{C}\right)$ : molar ratio ascorbic acid to oleic acid 1:9, $30 \mathrm{wt} \%$ of enzyme concentration, $125 \mathrm{rpm}$ in a tert-butanol solvent system.

As can be observed in Fig. 4, the increase in temperature influences the ascorbyl oleate (AO) production already in the initial phase of the reaction. The high yield was obtained at the high temperature $\left(70{ }^{\circ} \mathrm{C}\right)$ evaluated with $50 \%$ of conversion in $1 \mathrm{~h}$ of reaction. At high temperatures, the reaction rate increases because the kinetic energy of the molecules also increases, which facilitates effective collisions and interactions between the substrate 
molecules and the catalyst [35]. However, at $70{ }^{\circ} \mathrm{C}$ a lower final conversion was observed in relation to 55 and $40{ }^{\circ} \mathrm{C}$, probably because of the thermal deactivation of lipase [36]. In addition, it can be seen that after $1 \mathrm{~h}$ of reaction, there was a gradual decrease in the reaction yield due to the hydrolysis or oxidation of the ascorbic acid exposed to the high temperature [37].

The effect of temperature on the reaction rate was described by the Arrhenius (Equation 1). Fig. 5 presents the comparison of the initial calculated rate with the experimental one obtained by the Arrhenius equation by non-linear regression.

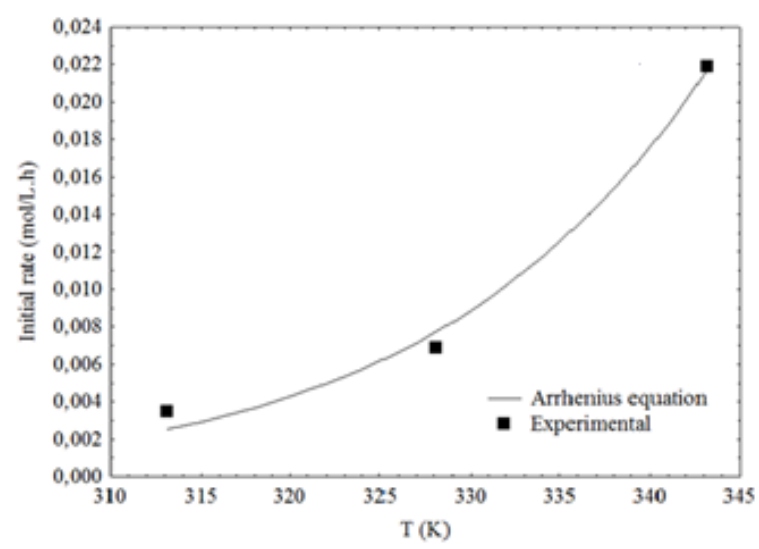

Figure 5. Effect of the temperature on the initial reaction rate obtained experimentally and by the Arrhenius equation.

It was observed an exponential behavior, determining an increasing trend in the initial rate of reaction with increasing temperature. A coefficient of determination of 0.99 was obtained between the initial rate of the experimental reaction and the calculated one. The estimated activation energy ( $\mathrm{Ea}$ ) was $64 \mathrm{~kJ} / \mathrm{mol}$, indicating that the reaction rate is sensitive to the temperature, based on the Arrhenius equation, i.e., the higher the Ea, the stronger the dependence between the rate constant and the temperature. Rani et al. [16] obtained $67.88 \mathrm{~kJ} / \mathrm{mol}$ for Ea of the esterification of oleic acid and decanol using Novozym 435 as a catalyst. Studies reported Ea in the range of 6.68-72.73 kJ/mol in enzymatic reactions using lipases of Candida antarctica, obtaining by linearized curve [38,39]. However, the Ea obtained in non-linear fit using the Arrhenius equation presented smaller errors in an exponential curve.

\subsection{Effect of enzyme concentration.}

The amount of catalyst loading was investigated in the range of 15, 20 and $30 \%$ (w/w substrates) at the optimum temperature of $70{ }^{\circ} \mathrm{C}$, molar ratio 1:9 (ascorbic acid/oleic acid), $30 \%$ of substrates of enzymatic charge, and agitation speed of $125 \mathrm{rpm}$, obtaining the kinetic curve (Fig. 6). As can be observed, with the increase of the catalytic charge, the conversion of ascorbyl oleate increases proportionally in the number of active sites, this is possible, since a greater amount of enzyme favors the reaction rate [40]. The maximum conversion (50\%) was obtained for high catalyst loading ( $30 \% \mathrm{w} / \mathrm{w}$ substrates) in $1 \mathrm{~h}$ of reaction, indicating that the increase of enzyme positively affects the reaction rate.

Chang et al. [30], obtained the highest yield in the synthesis of ascorbyl palmitate using $34.5 \%$ enzyme in $6.7 \mathrm{~h}$ with Novozym 435. However, what differs our study from other investigations is the low cost of immobilization of NS 88011 from commercially used ones, such as Novozym 435, since there is a concern related to the amount of enzyme and the 
economic viability of the process. In addition, the reaction time is much shorter than that observed in the literature, leading to more efficient syntheses.

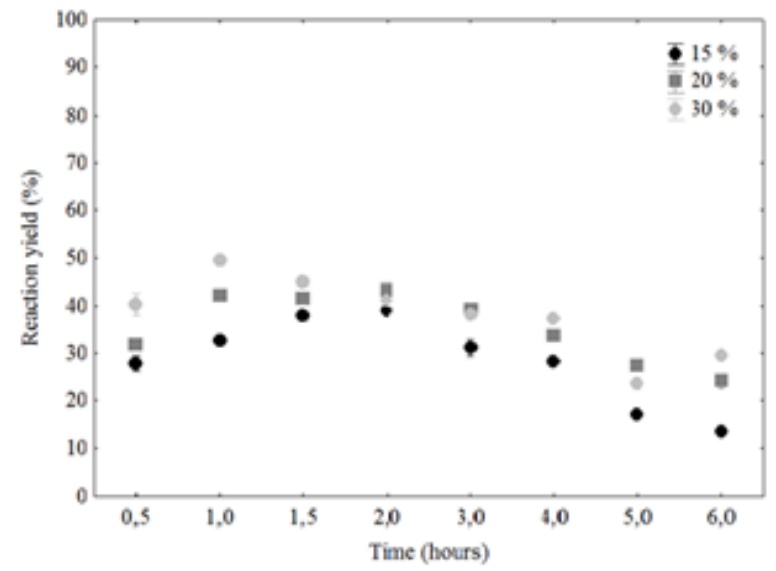

Figure 6. Kinetics of ascorbyl oleate production at different enzyme concentrations (15, 20, and $30 \mathrm{wt} \%$ ): molar ratio ascorbic acid to oleic acid $1: 9,70{ }^{\circ} \mathrm{C}, 125 \mathrm{rpm}$ in a tert-butanol solvent system.
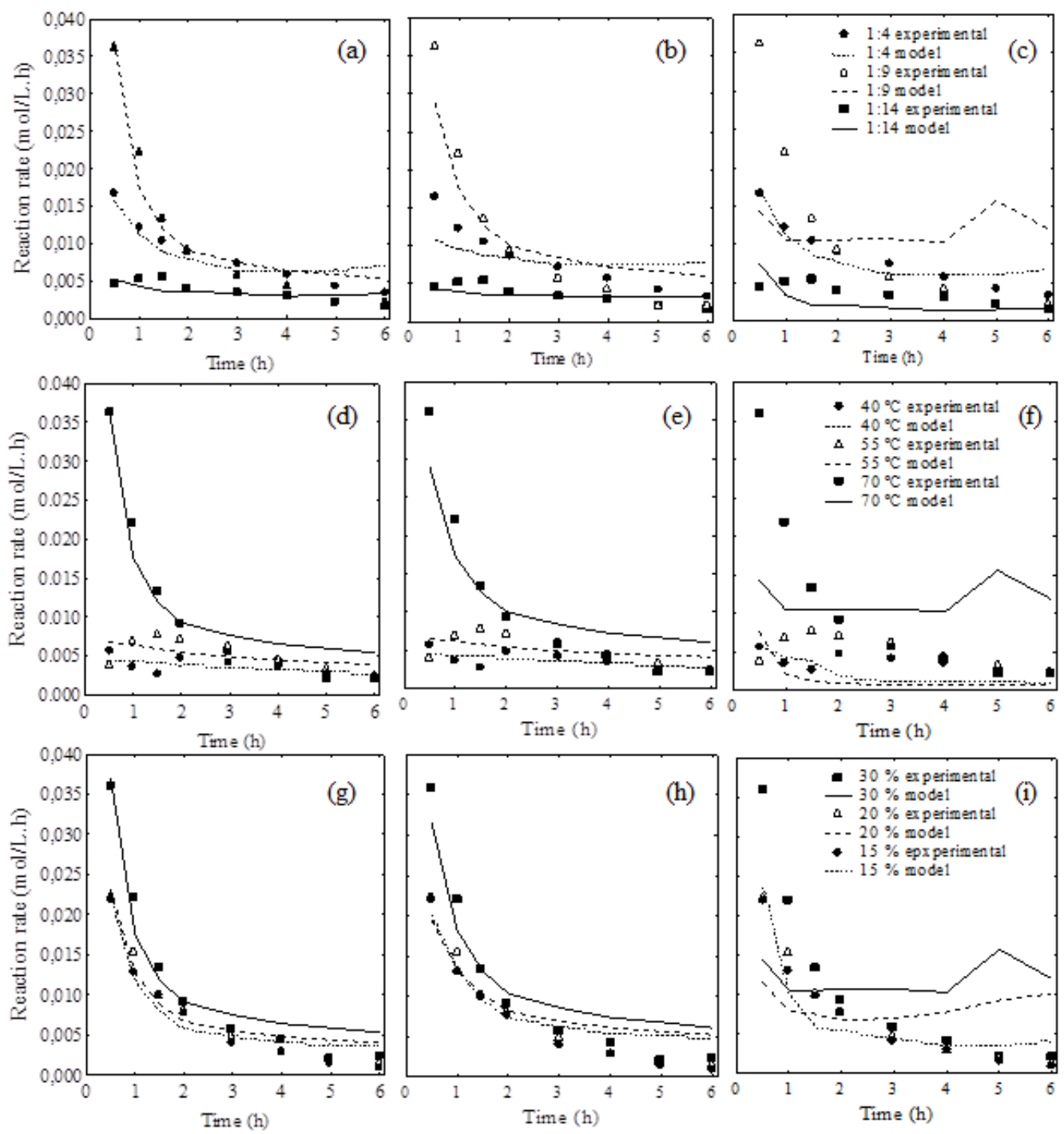

Figure 7. Experimental results (points) and simulated (line) by the Ping Pong Bi-Bi (a), (d) e (g), ordered Bi-Bi (b), (e) e (h), and random Bi-Bi (c), (f) e (i) models for the reaction conditions: molar ratio (a), (b) e (c), temperature (d), (e) e (f) and enzyme concentration (g), (h) e (i). 


\subsection{Mechanism of reaction.}

Several mechanisms have been proposed to explain reactions catalase by lipase (transesterification, esterification, interesterification), and it is observed that the most common and most accepted description of the catalytic action is given by the Ping Pong Bi-Bi mechanism [23,41]. Ping $\mathrm{Bi}-\mathrm{Bi}$, ordered $\mathrm{Bi}-\mathrm{Bi}$, and random $\mathrm{Bi}-\mathrm{Bi}$ were investigated to evaluate the initial rates based on their mechanism using the Generalized Reduced Gradient (GRG) algorithm in the Microsoft Excel Solver. The GRG algorithm is a robust and reliable method that can be implemented in enzymatic kinetic modeling. This optimization algorithm requires the preset initial parameter values to start the iterative process to provide the solutions then and converge to a predefined value $[42,43]$. Through this tool, many models and kinetic estimations have been investigated in the literature [19,44-46]. The dominant mechanism for molar ratio (1:4, 1:9 and 1:14 ascorbic acid-oleic acid), temperature (40,55 and $\left.70{ }^{\circ} \mathrm{C}\right)$, and amount of enzyme $(15,20$, and $30 \mathrm{w} / \mathrm{w}$ substrates $)$ in the synthesis of ascorbyl oleate catalyzed by NS 88011.

Table 1. Comparison of the kinetic parameters evaluated in the different experimental conditions for the PingPong Bi-Bi kinetic mechanism.

\begin{tabular}{|c|c|c|c|c|c|c|c|c|}
\hline \multirow{2}{*}{\multicolumn{2}{|c|}{ Condition }} & \multicolumn{6}{|c|}{ Parameter } & \multirow[b]{2}{*}{ Rmsd } \\
\hline & & Vm & $\mathbf{K m}_{\mathbf{a}}$ & $\mathbf{K m}_{\mathbf{b}}$ & $\mathbf{K} \mathbf{i}_{\mathbf{a}}$ & $\mathbf{K i}_{\mathbf{b}}$ & $\mathbf{R}^{2}$ & \\
\hline \multirow{3}{*}{$\begin{array}{l}\text { Molar ratio } \\
\text { (ascorbic acid: } \\
\text { oleic acid) }\end{array}$} & $1: 14$ & 0.0127 & 0,1005 & 0.1005 & 0.011 & 0.0099 & 0.67 & 0.00099 \\
\hline & $1: 9$ & 0.8890 & 0.1058 & 0.0754 & 1.959 & 0.0008 & 0.96 & 0.00266 \\
\hline & $1: 4$ & 0.2531 & 0.1013 & 0.1013 & 0.165 & 0.0006 & 0.88 & 0.00179 \\
\hline \multirow{3}{*}{ Temperature $\left({ }^{\circ} \mathrm{C}\right)$} & 70 & 0.8890 & 0.1058 & 0.0754 & 1.959 & 0.0008 & 0.96 & 0.00266 \\
\hline & 55 & 0.0137 & 0.1002 & 0.0971 & 0.411 & 0.0703 & 0.65 & 0.00148 \\
\hline & 40 & 0.0093 & 0.1003 & 0.0999 & 0.101 & 0.0609 & 0.72 & 0.00084 \\
\hline \multirow{3}{*}{$\begin{array}{l}\text { Enzyme concentration } \\
\text { (w/w substrates) }\end{array}$} & 15 & 0.1601 & 0.1006 & 0.1000 & 0.095 & 0.0021 & 0.94 & 0.00175 \\
\hline & 20 & 0.1149 & 0.1013 & 0.0991 & 0.184 & 0.0038 & 0.94 & 0.00190 \\
\hline & 30 & 0.8890 & 0.1058 & 0.0754 & 1.959 & 0.0008 & 0.96 & 0.00266 \\
\hline
\end{tabular}

Table 2. Comparison of the kinetic parameters evaluated in the conditions molar ratio, temperature, and enzyme concentration in the ordered $\mathrm{Bi}-\mathrm{Bi}$ mechanism.

\begin{tabular}{|c|c|c|c|c|c|c|c|c|}
\hline \multirow{2}{*}{\multicolumn{2}{|c|}{ Condition }} & \multicolumn{6}{|c|}{ Parameter } & \multirow{3}{*}{$\begin{array}{c}\text { Rmsd } \\
0.00106\end{array}$} \\
\hline & & \multirow{2}{*}{$\begin{array}{c}\mathbf{V m} \\
0.0002\end{array}$} & \multirow{2}{*}{$\begin{array}{c}\mathbf{K m}_{\mathbf{a}} \\
0.1236\end{array}$} & \multirow{2}{*}{$\begin{array}{c}\mathbf{K m}_{\mathbf{b}} \\
0.1986\end{array}$} & \multirow{2}{*}{$\begin{array}{c}\mathbf{K i}_{\mathbf{a}} \\
0.175\end{array}$} & \multirow{2}{*}{$\begin{array}{c}\mathbf{K i}_{\mathbf{b}} \\
0.0324\end{array}$} & \multirow{2}{*}{$\begin{array}{c}\mathbf{R}^{\mathbf{2}} \\
0.64 \\
\end{array}$} & \\
\hline Molar ratio & $1: 14$ & & & & & & & \\
\hline (ascorbic acid: & $1: 9$ & 0.0013 & 0.1778 & 0.1606 & 0.119 & 0.0177 & 0.96 & 0.00399 \\
\hline oleic acid) & $1: 4$ & 0.0003 & 0.2626 & 0.2472 & 0.079 & 0.0874 & 0.67 & 0.00308 \\
\hline \multirow{3}{*}{ Temperature $\left({ }^{\circ} \mathrm{C}\right)$} & 70 & 0.0013 & 0.1778 & 0.1606 & 0.119 & 0.0177 & 0.96 & 0.00399 \\
\hline & 55 & 0.0002 & 0.0386 & 0.1550 & 0.247 & 0.2828 & 0.64 & 0.00150 \\
\hline & 40 & 0.0002 & 0.0750 & 0.1877 & 0.198 & 0.1976 & 0.72 & 0.00084 \\
\hline \multirow{3}{*}{$\begin{array}{l}\text { Enzyme concentration } \\
\text { (w/w substrates) }\end{array}$} & 15 & 0.0009 & 0.1558 & 0.1715 & 0.147 & 0.0168 & 0.95 & 0.00234 \\
\hline & 20 & 0.0007 & 0.1520 & 0.1688 & 0.145 & 0.0279 & 0.94 & 0.00268 \\
\hline & 30 & 0.0013 & 0.1779 & 0.1606 & 0.119 & 0.0177 & 0.96 & 0.00399 \\
\hline
\end{tabular}

Table 3. Comparison of the kinetic parameters evaluated in the molar ratio, temperature, and enzyme concentration conditions in the random Bi-Bi mechanism.

\begin{tabular}{|c|c|c|c|c|c|c|c|}
\hline \multirow{2}{*}{\multicolumn{2}{|c|}{ Condition }} & \multicolumn{6}{|c|}{ Parameter } \\
\hline & & Vm & $\mathbf{K m}_{\mathbf{a}}$ & $\mathbf{K m}_{\mathbf{b}}$ & $\mathbf{K} \mathbf{i}_{\mathbf{a}}$ & $\mathbf{R}^{2}$ & Rmsd \\
\hline \multirow{3}{*}{$\begin{array}{l}\text { Molar ratio } \\
\text { (ascorbic acid: } \\
\text { oleic acid) }\end{array}$} & $1: 14$ & $3.67 \times 10^{-6}$ & 0.321 & 0.192 & 0.321 & 0.36 & 0.00200 \\
\hline & $1: 9$ & $4.68 \times 10^{-5}$ & 0.060 & 0.161 & 0.060 & 0.14 & 0.01093 \\
\hline & $1: 4$ & $2.78 \times 10^{-6}$ & 0.061 & 0.189 & 0.061 & 0.89 & 0.00166 \\
\hline \multirow{3}{*}{ Temperature $\left({ }^{\circ} \mathrm{C}\right)$} & 70 & $4.64 \times 10^{-5}$ & 0.060 & 0.1612 & 0.060 & 0.14 & 0.01087 \\
\hline & 55 & $5.24 \times 10^{-6}$ & 0.965 & 0.179 & 0.965 & 0.007 & 0.00455 \\
\hline & 40 & $4.16 \times 10^{-6}$ & 0.358 & 0.188 & 0.358 & 0.34 & 0.00194 \\
\hline \multirow{3}{*}{$\begin{array}{l}\text { Enzyme concentration } \\
\text { (w/w substrates) }\end{array}$} & 15 & $1.09 \times 10^{-5}$ & 0.175 & 0.184 & 0.175 & 0.88 & 0.00241 \\
\hline & 20 & $2.72 \times 10^{-5}$ & $5.79 \times 10^{-4}$ & 0.169 & $5.79 \times 10^{-4}$ & 0.23 & 0.00650 \\
\hline & 30 & $4.66 \times 10^{-5}$ & 0.0605 & 0.161 & 0.0605 & 0.14 & 0.01093 \\
\hline
\end{tabular}


The reaction rates are presented in Fig. 7 for the data obtained experimentally and adjusted by the models conducted in this study. The calculated kinetic constants (Equations 4, 5 , and 6) by the non-linear regression method are reported in Tables 1, 2, and 3.

Satisfactory values obtained from the determination coefficient (between 0.65 and 0.96 ) of the Ping Pong Bi-Bi model with inhibition by both substrates was adequate to represent the relation between the experimental and theoretical parameters for the three parameters investigated (molar ratio, temperature, and enzyme concentration), as well as presenting a lower Root Mean Square deviation (Rmsd - between 0.00099 and 0.00266), followed by ordered Bi-Bi, which can be clearly seen in Fig. 7. The random Bi-Bi model proved not to be appropriate to represent the reaction.

Taking into account the Ping Pong Bi-Bi model that presented the best performance, the molar ratio 1:9 (ascorbic acid:oleic acid), the temperature of $70{ }^{\circ} \mathrm{C}$ and $30 \%$ of enzyme concentration (w/w substrates) in $1 \mathrm{~h}$ of reaction presented higher kinetic constant $\mathrm{Vm}$ in comparison with the other conditions, coinciding with the maximum reaction yields presented previously (Fig. 3, 4 and 6), thus, indicating a high reaction rate in this condition due to the faster division of the complex enzyme-substrate to form the product. Given the above, a promising performance of the new enzyme (NS 88011) is observed for the production of ascorbyl oleate.

The estimated value of the $\mathrm{Km}$ constant remained practically the same for all tested conditions, indicating that none of the parameters have adverse effects on the formation of the enzyme-substrate complex during the catalytic reaction. In addition, the $\mathrm{Km}$ constant is similar for both substrates, suggesting a similar affinity to ascorbic acid and oleic acid by the biocatalyst. Basheer et al. [47] reported a similar binding affinity of a lipase (R. japonica) for both substrates in the esterification between lauric acid $(\mathrm{Km}=10.6 \mathrm{mmol} / \mathrm{L})$ and dodecyl alcohol $(\mathrm{Km}=11.9 \mathrm{mmol} / \mathrm{L})$. Chowdhury and Mitra [30] also documented the affinity of the substrates (free fatty acids and octyl alcohol) to lipase (Novozym 435), with $\mathrm{Km}$ of $1.08 \mathrm{~mol} / \mathrm{L}$ and $2.07 \mathrm{~mol} / \mathrm{L}$, respectively.

In all tested conditions, oleic acid showed a low inhibitory constant (Kib) when compared to Kia, indicating that oleic acid does not have a great inhibitory effect than ascorbic acid. This is important since the ratio of the substrates can influence the mass transfer of the reaction system, since an excessive amount of acyl donor is beneficial for the fast formation of the enzymatic acyl complex, allowing the equilibrium position towards high concentrations of the product and at low molar concentrations to a limitation in mass transfer [8,10]. Oleic acid is highly hydrophobic $(\log \mathrm{P}=7.64)$, so it is expected to have a high affinity to the hydrophobic surface of the carrier. In the present study, we observed a great influence of the ascorbic acid inhibition constant $(\mathrm{Ki}=1.959)$ in the optimal condition $\left(1: 9\right.$ ascorbic acid-oleic acid, $70{ }^{\circ} \mathrm{C}$ and $30 \% \mathrm{w} / \mathrm{w}$ substrates), as well as in all other assays, but with less inhibitory intensity.

There are two possible explanations proposed for alcohol inhibition. First, inhibition may be related to the reversible reaction process, where part of the ester formed returns the enzyme-substrate step, taking into account that the high reaction rate was obtained in the initial phase, followed by the decrease as a function of time. This may be possible because there may be an accumulation of water as the reaction progresses, which causes ester hydrolysis [49]. With ester hydrolysis, ascorbic acid is released, and under certain conditions, this may lead to the formation of an inactive complex between alcohol (in our reaction, this role is ascorbic acid) and the enzyme $[11,50]$. Subsequently cannot be transformed into a product, that is, the 
substrate ascorbic acid cannot bind to the acyl-enzyme complex, thus agreeing with the acid inhibition and a decrease in the reaction rate (Fig. 7), as well as in the conversion (Fig. 3, 4 and 6). In a previously reported study, alcohols are indicated as terminal lipase inhibitors [51]. Discrepancies between reported kinetic models indicate that the size, branching, and abundance of hydroxyl groups in the side chains of both substrates strongly affect the reaction mechanism [11]. Second, because the alcohol in our reaction is an acid, it can cause acidification of the aqueous micro-layer interface leading to enzymatic inactivation [41].

In previous studies of ester synthesis with lipase, Ping Pong Bi-Bi models with inhibition by different substrates or without any substrate inhibition were postulated [11,41,50,52-55].

In several kinetic studies conducted in batch bioreactors, it was shown that the Ping Pong Bi-Bi model with inhibition by ascorbic acid was adequate for the adjustment of experimental data $[11,22,56]$. This model adequately describes the synthesis of ascorbyl oleate catalyzed by Novozym ${ }^{\circledR} 435$ in a batch system. Once the new immobilized preparation has been applied, kinetic parameters, including rates of esterification, should be investigated, as the affinity with the enzyme may be different. Corović et al. [21], in a study using Candida antarctica lipase B and the same substrates, did not observe inhibition by vitamin C, probably because of the difference in immobilization support. They observed better performance to the Bi - Bi Ping Pong mechanism with low inhibition of the acyl donor.

Although several mechanisms have been proposed, in our results, the Ping Pong Bi Bi mechanism with inhibition for both substrates showed better performance.

\subsection{Operational stability of the enzyme.}

The recycling of the enzyme is a critical factor in evaluating the economic viability of the enzyme-catalyzed process. Upon completion of the reaction, i.e., $1 \mathrm{~h}$, the immobilized enzyme was filtered, washed with n-hexane, and reused to analyze the extent of reuse. As shown in Fig. 8, lipase activity reduced by approximately half to initial was in the $14^{\text {th }}$ cycle, indicating good operational stability under the reaction conditions of this study for the synthesis of ascorbyl oleate. The $50 \%$ reduction in lipase activity after $14 \mathrm{~h}$ of the reaction may be related to the influence of solvent on enzyme activity, since, in the preliminary test we observed that tert-butanol could affect the enzyme's hydration layer and reduce the $50 \%$ enzymatic activity after $16 \mathrm{~h}$ in contact with the solvent at $70{ }^{\circ} \mathrm{C}$.

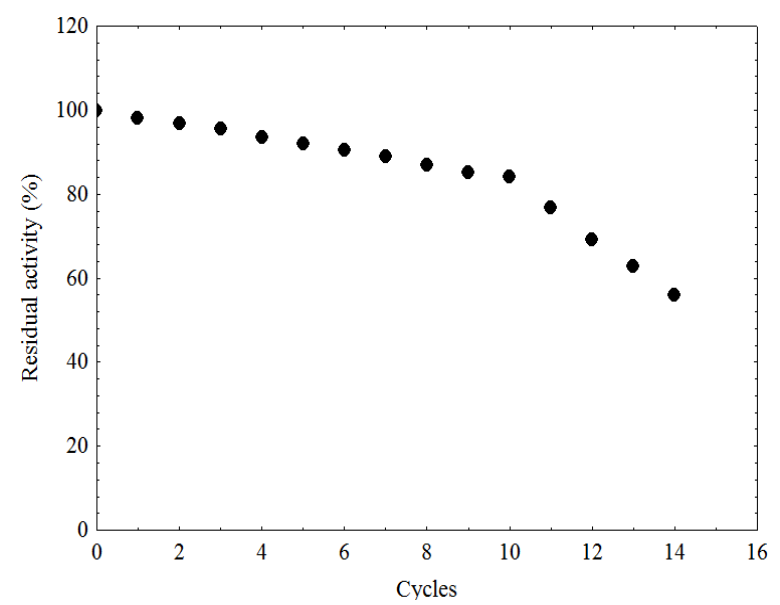

Figure 8. Operational stability of NS 88011 under maximized reaction conditions. 
Balen et al. [8] in reactions tested at 60 and $70{ }^{\circ} \mathrm{C}, 1: 9$ molar ratio (ascorbic acid: oleic acid); $5 \%$ Novozym 435; $2 \mathrm{~mL}$ of tert-butanol, $2 \mathrm{~h}$ with microwave irradiation observed that, in the third cycle of use, the enzyme Novozym 435 dramatically decreased the conversion value of ascorbyl oleate (reduction approximately 5 times in the first cycle).

In addition to greater operational stability, it is important to analyze the economic feasibility of applying lipolytic enzymes. The main disadvantage in industrial use, for example, Novozym 435 (Novozymes) is associated with the high cost. In view of this, the development of economically viable supports opens up new possibilities for applications mainly on an industrial scale, demonstrating the advantage of NS 88011, immobilized with low-cost material, formulated by Novozymes.

\section{Conclusions}

The development of the enzymatic process with the new low-cost enzyme preparation proved to be efficient for the synthesis of ascorbyl oleate. It was observed that the conditions as a molar ratio, temperature, and enzymatic charge were important effects to obtain high conversion. A maximum conversion of $50 \%$ was observed under optimized conditions. The lipase showed excellent operational stability, and the kinetic study showed that the Ping Pong $\mathrm{Bi}-\mathrm{Bi}$ model with inhibition for both substrates was adequate to represent the experimental data for all tested effects. In summary, the results of this study may make an important contribution to the elucidation of the mechanism of synthesis of vitamin C catalase catalyzed by lipase NS 88011, offering a good perspective for the development of industrial processes due to the presented economic viability of the biocatalyst when compared to commonly used.

\section{Funding}

This research received no external funding.

\section{Acknowledgments}

This work was supported by the Coordenação de Aperfeiçoamento de Pessoal de Nível Superior - Brasil (CAPES), the Conselho Nacional de Desenvolvimento Científico e Tecnológico (CNPq) and the Universidade Regional Integrada do Alto Uruguai e das Missões (URI) scholarships and / or financial support.

\section{Conflicts of Interest}

The authors declare no conflict of interest.

\section{References}

1. Sharma, S.; Cheng, S.F.; Bhattacharya, B.; Chakkaravarthi, S. Efficacy of free and encapsulated natural antioxidants in oxidative stability of edible oil: Special emphasis on nanoemulsion-based encapsulation. Trends Food Sci. Technol. 2019, 91, 305-318, https://doi.org/10.1016/j.tifs.2019.07.030.

2. Cruz, R.G. da; Beney, L.; Gervais, P.; Lira, S.P. de; Vieira, T.M.F. de S.; Dupont, S. Comparison of the antioxidant property of acerola extracts with synthetic antioxidants using an in vivo method with yeasts. Food Chem. 2019, 277, 698-705, https://doi.org/10.1016/j.foodchem.2018.10.099.

3. Ribeiro, J.S.; Santos, M.J.M.C.; Silva, L.K.R.; Pereira, L.C.L.; Santos, I.A.; Lannes, S.C. da S.; Silva, M.V. Natural antioxidants used in meat products: A brief review. Meat Sci. 2019, 148, 181-188, https://doi.org/10.1016/j.meatsci.2018.10.016.

4. Vieitez, I.; Maceiras, L.; Jachmanián, I.; Alborés, S. Antioxidant and antibacterial activity of different extracts from herbs obtained by maceration or supercritical technology. J. Supercrit. Fluids 2018, 133, 58- 
64, https://doi.org/10.1016/j.supflu.2017.09.025.

5. Stojanović, M.; Carević, M.; Mihailović, M.; Veličković, D.; Dimitrijević, A.; Milosavić, N.; Bezbradica, D. Influence of fatty acid on lipase-catalyzed synthesis of ascorbyl esters and their free radical scavenging capacity. Biotechnol. Appl. Biochem. 2015, 62, 458-466, https://doi.org/10.1002/bab.1296.

6. Watanabe, Y.; Nakanishi, H.; Goto, N.; Otsuka, K.; Kimura, T.; Adachi, S. Antioxidative Properties of Ascorbic Acid and Acyl Ascorbates in ML/W Emulsion. J. Am. Oil Chem. Soc. 2010, 87, 1475-1480, https://doi.org/10.1007/s11746-010-1632-8.

7. Ćorović, M.; Milivojević, A.; Carević, M.; Banjanac, K.; Vujisić, L.; Pjanović, R.; Bezbradica, D. Enzymatic lipophilization of vitamin $\mathrm{C}$ with linoleic acid: Determination of antioxidant and diffusion properties of L-ascorbyl linoleate. Food Feed Res. 2018, 45, 1-10, https://doi.org/10.5937/ffr1801001c.

8. Balen, M.; Silveira, C.; Kratz, J.M.; Simões, C.M.O.; Valério, A.; Ninow, J.L.; Nandi, L.G.; Di Luccio, M.; Oliveira, D. Novozym ${ }^{\circledR} 435$-catalyzed production of ascorbyl oleate in organic solvent ultrasound-assisted system. Biocatal. Agric. Biotechnol. 2015, 4, 514-520, https://doi.org/10.1016/j.bcab.2015.08.008.

9. Balen, M.; Gomes, G.R.; Kratz, J.M.; Simões, C.M.O.; Valério, A.; Oliveira, D. Enzymatic synthesis of ascorbyl ester derived from linoleic acid. Bioprocess Biosyst. Eng. 2017, 40, 265-270. https://doi.org/10.1007/s00449-016-1694-6.

10. Lerin, L. A.; Richetti, A.; Dallago, R.; Treichel, H.; Mazutti, M. A.; Oliveira, J. V.; Antunes, O.A.C.; Oestreicher, E.G.; Oliveira, D. Enzymatic Synthesis of Ascorbyl Palmitate in Organic Solvents: Process Optimization and Kinetic Evaluation. Food Bioprocess Technol. 2012, 5, 1068-1076, https://doi.org/10.1007/s11947-010-0398-1.

11. Bezbradica, D.; Stojanović, M.; Veličković, D.; Dimitrijević, A.; Carević, M.; Mihailović, M.; Milosavić, N. Kinetic model of lipase-catalyzed conversion of ascorbic acid and oleic acid to liposoluble vitamin C ester. Biochem. Eng. J. 2013, 71, 89-96, https://doi.org/10.1016/j.bej.2012.12.001.

12. Reyes-Duarte, D.; Lopez-Cortes, N.; Torres, P.; Comelles, F.; Parra, J.L.; Peña, S.; Ugidos, A. V.; Ballesteros, A.; Plou, F.J. Synthesis and Properties of Ascorbyl Esters Catalyzed by Lipozyme TL IM using Triglycerides as Acyl Donors. J. Am. Oil Chem. Soc. 2011, 88, 57-64, https://doi.org/10.1007/s11746-0101643-5.

13. Gawas, S.D.; Lokanath, N.; Rathod, V.K. Optimization of enzymatic synthesis of ethyl hexanoate in a solvent free system using response surface methodology (RSM). Biocatalysis 2018, 4, 14-26, https://doi.org/10.1515/boca-2018-0002.

14. Costa, I.C.R.; Sutili, F.K.; Silva, G.V.V.; Leite, S.G.F.; Miranda, L.S.M.; Souza, R.O.M.A. Lipase catalyzed ascorbyl palmitate synthesis under microwave irradiation. J. Mol. Catal. B Enzym. 2014, 102, 127-131, https://doi.org/10.1016/J.MOLCATB.2014.02.002.

15. Zhang, D.H.; Li, C.; Xie, L.L.; Yuwen, L.X. Enzymatic synthesis of 1 -Ascorbyl Laurate in DMSO-Acetone Mixed Solvent. Ind. Eng. Chem. Res. 2013, 52, 11875-11879, https://doi.org/10.1021/ie4016396.

16. Rani, K.N.P.; Neeharika, T.S.V.R.; Kumar, T.P.; Satyavathi, B.; Sailu, C.; Prasad, R.B.N. Kinetics of enzymatic esterification of oleic acid and decanol for wax ester and evaluation of its physico-chemical properties. J. Taiwan Inst. Chem. Eng. 2015, 55, 12-16, https://doi.org/10.1016/J.JTICE.2015.04.011.

17. Ćorović, M.; Milivojević, A.; Simović, M.; Banjanac, K.; Pjanović, R.; Bezbradica, D. Enzymatically derived oil-based L-ascorbyl esters: Synthesis, antioxidant properties and controlled release from cosmetic formulations. Sustain. Chem. Pharm. 2020, 15, https://doi.org/10.1016/j.scp.2020.100231.

18. Yadav, M. G.; Kavadia, M. R.; Vadgama, R.N.; Odaneth, A.A.; Lali, A.M. Production of 6-O-1-Ascorbyl Palmitate by Immobilized Candida antarctica Lipase B. Appl. Biochem. Biotechnol. 2018, 184, 1168-1186, https://doi.org/10.1007/s12010-017-2610-5.

19. Waghmare, G. V.; Chatterji, A.; Rathod, V.K. Kinetics of Enzymatic Synthesis of Cinnamyl Butyrate by Immobilized Lipase. Appl. Biochem. Biotechnol. 2017, 183, 792-806, https://doi.org/10.1007/s12010-0172464-x.

20. More, S.B.; Waghmare, J.S.; Gogate, P.R.; Naik, S.N. Improved synthesis of medium chain triacylglycerol catalyzed by lipase based on use of supercritical carbon dioxide pretreatment. Chem. Eng. J. 2018, 334, 1977-1987, https://doi.org/10.1016/j.cej.2017.11.122.

21. Ćorović, M.; Milivojević, A.; Carević, M.; Banjanac, K.; Jakovetić Tanasković, S.; Bezbradica, D.Batch and semicontinuous production of 1-ascorbyl oleate catalyzed by CALB immobilized onto Purolite ${ }^{\circledR}$ MN102. Chem. Eng. Res. Des. 2017, 126, 161-171, https://doi.org/10.1016/j.cherd.2017.08.021.

22. Zhang, D.H.; Li, C.; Zhi, G.Y. Kinetic and thermodynamic investigation of enzymatic l-ascorbyl acetate synthesis. J. Biotechnol. 2013, 168, 416-420, https://doi.org/10.1016/J.JBIOTEC.2013.10.033.

23. Kuperkar, V.V.; Lade, V.G.; Prakash, A.; Rathod, V.K. Synthesis of isobutyl propionate using immobilized lipase in a solvent free system: Optimization and kinetic studies. J. Mol. Catal. B Enzym. 2014, 99, 143-149, https://doi.org/10.1016/J.MOLCATB.2013.10.024.

24. Khan, N.R.; Gawas, S.D.; Rathod, V.K. Enzyme-catalysed production of n-butyl palmitate using ultrasoundassisted esterification of palmitic acid in a solvent-free system. Bioprocess Biosyst. Eng. 2018, 41, 16211634, https://doi.org/10.1007/s00449-018-1988-y.

25. Mashhadi, F.; Habibi, A.; Varmira, K. Determination of Activation Energy and Ping-Pong Kinetic Model Constants of Enzyme-Catalyzed Self-Epoxidation of Free Fatty Acids using Micro-reactor. Catal. Letters. 
2018, 148, 3236-3247, https://doi.org/10.1007/s10562-018-2503-4.

26. Jaiswal, K.S.; Rathod, V.K. Enzymatic synthesis of cosmetic grade wax ester in solvent free system: optimization, kinetic and thermodynamic studies. SN Appl. Sci. 2019, 1, 1-11, https://doi.org/10.1007/s42452-019-0955-9.

27. Ahranjani, P.E.; Kazemeini, M.; Arpanaei, A. Green Biodiesel Production from Various Plant Oils Using Nanobiocatalysts Under Different Conditions. Bioenergy Res. 2019, 13, 552-562, https://doi.org/10.1007/s12155-019-10022-9.

28. Karmee, S.K. Biocatalytic synthesis of ascorbyl esters and their biotechnological applications. Appl. Microbiol. Biotechnol. 2009, 81, 1013-1022, https://doi.org/10.1007/s00253-008-1781-y.

29. Tufiño, C.; Bernal, C.; Ottone, C.; Romero, O.; Illanes, A.; Wilson, L. Synthesis with Immobilized Lipases and Downstream Processing of Ascorbyl Palmitate. Molecules. 2019, 24, https://doi.org/10.3390/molecules24183227.

30. Chang, S.W.; Yang, C.J.; Chen, F.Y.; Akoh, C.C.; Shieh, C.J. Optimized synthesis of lipase-catalyzed 1ascorbyl laurate by Novozym ${ }^{\circledR}$ 435. J. Mol. Catal. B Enzym. 2009, 56, 7-12, https://doi.org/10.1016/j.molcatb.2008.04.001.

31. Instituto Adolfo Lutz, Métodos físico-químicos para análise de alimentos. 4th ed.; São Paulo, Brasil, 2008; pp. 1020.

32. Rigo, E.; Ninow, J.L.; Luccio, M. Di; Oliveira, J.V.; Polloni, A.E.; Remonatto, D. Arbter, F.; Vardanega, R.; Oliveira, D. de; Treichel, H. Lipase production by solid fermentation of soybean meal with different supplements. LWT - Food Sci. Technol. 2010, 43, 1132-1137, https://doi.org/10.1016/J.LWT.2010.03.002.

33. Bernardes, O.L.; Bevilaqua, J. V.; Leal, M.C.M.R.; Freire, D.M.G.; Langone, M.A.P. Biodiesel fuel production by the transesterification reaction of soybean oil using immobilized lipase. Appl. Biochem. Biotechnol. 2007, 137-140, 105-114, https://doi.org/10.1007/s12010-007-9043-5.

34. Gharat, N.; Rathod, V.K. Ultrasound assisted enzyme catalyzed transesterification of waste cooking oil with dimethyl carbonate. Ultrason. Sonochem. https://doi.org/10.1016/J.ULTSONCH.2012.10.011.

35. Rodriguez-Nogales, J.M.; Roura, E.; Contreras, E. Biosynthesis of ethyl butyrate using immobilized lipase: a statistical approach. Process Biochem. 2005, 40, 63-68, https://doi.org/10.1016/J.PROCBIO.2003.11.049.

36. Yadav, G.D.; Dhoot, S.B.; Immobilized lipase-catalysed synthesis of cinnamyl laurate in non-aqueous media. J. Mol. Catal. B Enzym. 2009, 57, 34-39, https://doi.org/10.1016/j.molcatb.2008.06.013.

37. Austria, R.; Semenzato, A.; Bettero, A. Stability of vitamin C derivatives in solution and topical formulations. J. Pharm. Biomed. Anal. 1997, 15, 795-801, https://doi.org/10.1016/S0731-7085(96)019048.

38. Yadav, G.D.; Borkar, I.V. Kinetic Modeling of Immobilized Lipase Catalysis in Synthesis of n-Butyl Levulinate $\dagger$. 2008, 47, 3358-3363, https://doi.org/10.1021/IE800193F.

39. Ciftci, O.N.; Temelli, F. Enzymatic conversion of corn oil into biodiesel in a batch supercritical carbon dioxide reactor and kinetic modeling. J. Supercrit. Fluids 2013, 75, 172-180, https://doi.org/10.1016/J.SUPFLU.2012.12.029.

40. Rodrigues, R.C.; Volpato, G.; Wada, K.; Záchia Ayub, M.A. Improved Enzyme Stability in LipaseCatalyzed Synthesis of Fatty Acid Ethyl Ester from Soybean Oil. Appl. Biochem. Biotechnol. 2009, 152, 394-404, https://doi.org/10.1007/s12010-008-8218-z.

41. Bansode, S.R.; Hardikar, M.A.; Rathod, V.K. Evaluation of reaction parameters and kinetic modelling for Novozym 435 catalysed synthesis of isoamyl butyrate. J. Chem. Technol. Biotechnol. 2017, 92, 1306-1314, https://doi.org/10.1002/jctb.5125.

42. Zhang, Y.; Huo, M.; Zhou, J.; Xie, S. PKSolver: An add-in program for pharmacokinetic and pharmacodynamic data analysis in Microsoft Excel. Comput. Methods Programs Biomed. 2010, 99, 306314, https://doi.org/10.1016/j.cmpb.2010.01.007.

43. Wu, B.; Ako, R.; Hu, M. A Useful Microsoft Excel Add-in Program for Modeling Steady-state. Enzyme Kinetics. Pharm. Anal. Acta 2012, 01, 1-7, https://doi.org/10.4172/2153-2435.S11-003.

44. Taher, H.; Al-Zuhair, S.; Al-Marzouqi, A.H.; Haik, Y.; Farid, M. Enzymatic biodiesel production of microalgae lipids under supercritical carbon dioxide: Process optimization and integration. Biochem. Eng. J. 2014, 90, 103-113, https://doi.org/10.1016/j.bej.2014.05.019.

45. Devi, N.A.; Radhika, G.B.; Bhargavi, R.J. Lipase catalyzed transesterification of ethyl butyrate synthesis in n-hexane-a kinetic study. J. Food Sci. Technol. 2017, 54, 2871-2877, https://doi.org/10.1007/s13197-0172725-2.

46. Dasgupta, D.; Kurmi, A.K.; Adhikari, D.K.; Ghosh, D. Xylitol production from lignocellulosic pentosans using Kluyveromyces marxianus: kinetic modelling of yeast growth and fermentation. Biofuels 2020, 11, 309-319.

47. Basheer, S.; Cogan, U.; Nakajima, M. Esterification kinetics of long-chain fatty acids and fatty alcohols with a surfactant-coated lipase in $\mathrm{n}$-hexane. J. Am. Oil Chem. Soc. 1998, 75, 1785-1790, https://doi.org/10.1007/s11746-998-0332-0.

48. Chowdhury, A.; Mitra, D. A kinetic study on the Novozyme 435-catalyzed esterification of free fatty acids with octanol to produce octyl esters. Biotechnol. Prog. 2015, 31, 1494-1499, 
https://doi.org/10.1002/btpr.2165.

49. Hari Krishna, S.; Prapulla, S.G.; Karanth, N.G. Enzymatic synthesis of isoamyl butyrate using immobilized Rhizomucor miehei lipase in non-aqueous media. J. Ind. Microbiol. Biotechnol. 2000, 25, 147-154, https://doi.org/10.1038/sj.jim.7000045.

50. Yadav, G.D.; Lathi, P.S. Kinetics and mechanism of synthesis of butyl isobutyrate over immobilised lipases. Biochem. Eng. J. 2003, 16, 245-252, https://doi.org/10.1016/S1369-703X(03)00026-3.

51. Chowdary, G.V.; Ramesh, M.N.; Prapulla, S.G. Enzymic synthesis of isoamyl isovalerate using immobilized lipase from Rhizomucor miehei: a multivariate analysis. Process Biochem. 2000, 36, 331-339, https://doi.org/10.1016/S0032-9592(00)00218-1.

52. Arcos, J.A.; Hill, C.G.; Otero, C. Kinetics of the lipase-catalyzed synthesis of glucose esters in acetone. Biotechnol. Bioeng. 2001, 73, 104-10, https://doi.org/10.1002/bit.1042.

53. Yadav, G.D.; Devi, K.M. Immobilized lipase-catalysed esterification and transesterification reactions in nonaqueous media for the synthesis of tetrahydrofurfuryl butyrate: comparison and kinetic modeling. Chem. Eng. Sci. 2004, 59, 373-383, https://doi.org/10.1016/J.CES.2003.09.034.

54. Bezbradica, D.; Mijin, D.; Siler-Marinkovic, S.; Knezevic, Z. The Candida rugosa lipase catalyzed synthesis of amyl isobutyrate in organic solvent and solvent-free system: A kinetic study. J. Mol. Catal. B Enzym. 2006, 38, 11-16, https://doi.org/10.1016/J.MOLCATB.2005.10.004.

55. Raita, M.; Arnthong, J.; Champreda, V.; Laosiripojana, N. Modification of magnetic nanoparticle lipase designs for biodiesel production from palm oil. Fuel Process. Technol. 2015, 134, 189-197, https://doi.org/10.1016/J.FUPROC.2015.01.032.

56. Song, Q.X.; Wei, D.Z. Study of Vitamin C ester synthesis by immobilized lipase from Candida sp. J. Mol. Catal. B Enzym. 2002, 18, 261-266, https://doi.org/10.1016/S1381-1177(02)00104-2. 